\title{
Revision of the type material of the Pliocene species Prolagus bilobus Heller, 1936 (Mammalia, Lagomorpha), with comments on the taxonomic validity of $P$. osmolskae Fostowicz-Frelik, 2010
}

\author{
STANISLAV ČERMÁK \& CHIARA ANGELONE
}

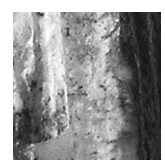

\begin{abstract}
The taxonomy of the Pliocene Prolagus in central Europe is still poorly understood. The proven record is limited there just onto P. bilobus from Gundersheim localities (Germany) and P. osmolskae from Raciszyn 1 (Poland). Unfortunately, the taxonomy of P. bilobus has until now remained unclear. Apart from the original description, no studies have provided data based on direct observation of the type material. Only minor attention has also been paid to a detailed analysis of additional material from the Gundersheim localities. Therefore, we are providing the first revision of the type material of $P$. bilobus accompanied by a synoptic survey of the type locality. Based on previously undescribed material of $P$. bilobus, we clarify the morphologic variability and dimensional range of $P$. bilobus, and question the validity of $P$. osmolskae. A direct revision of the both species evidenced that the only available specimen - the holotype - of $P$. osmolskae clearly falls within the recorded size and morphological range of the very large $P$. bilobus. And thus $P$. osmolskae Fostowicz-Frelik, 2010 is regarded here as a junior subjective synonym of $P$. bilobus Heller, 1936.

- Key words: Lagomorpha, Prolagidae, Prolagus bilobus, Prolagus osmolskae, Pliocene, Central Europe.
\end{abstract}

ČERMÁK, S. \& ANGELONE, C. 2013. Revision of the type material of the Pliocene species Prolagus bilobus Heller, 1936 (Mammalia, Lagomorpha), with comments on the taxonomic validity of P. osmolskae Fostowicz-Frelik, 2010. Bulletin of Geosciences 88(1), 45-50 (1 figure, 1 table). Czech Geological Survey, Prague. ISSN 1214-1119. Manuscript received June 4, 2012; accepted in revised form June 27, 2012; published online September 5, 2012; issued December 6, 2012.

Stanislav Čermák, Institute of Geology AS CR, v.v.i., Laboratory Paleobiology and Paleoecology, Rozvojová 269, CZ-165 00 Prague 6 - Lysolaje, Czech Republic; cermaks@gli.cas.cz・Chiara Angelone, Dipartimento di Scienze Geologiche, Università Roma Tre, Largo San Leonardo Murialdo 1, 00146 Roma, Italia; angelone@uniroma3.it

Taxonomy and phylogeny of Prolagus Pomel, 1853 from the Pliocene of central Europe are still poorly understood especially if compared with the Mediterranean region. The main reason is that the genus is relatively rare in the Pliocene of transalpine Europe. It is much more frequently recorded in the Mediterranean region, which seems to have been particularly attractive. The proven Pliocene record of Prolagus from central Europe is limited to three localities: Gundersheim (fissure 4 and Findling), Germany (P. bilobus Heller, 1936) and Raciszyn 1, Poland (P. osmolskae Fostowicz-Frelik, 2010). Its record from Wölfersheim, Germany ( $c f$. Tobien 1977 without description) cannot be confirmed, as the material is unavailable.

Unfortunately, until now, the taxonomy of Prolagus bilobus has remained unclear. Apart from the original description, no studies have provided data based on direct observation of the type material. Only minor attention has also been paid to a detailed analysis of additional material from the Gundersheim localities (cf. Fejfar et al. 2006).
Therefore, we are providing a revision of the type material of $P$. bilobus accompanied by a nomenclature survey of the different sites at Gundersheim. Based on previously undescribed material of $P$. bilobus, we clarify the morphologic variability and dimensional range of $P$. bilobus, and question the validity of $P$. osmolskae as described by Fostowicz-Frelik (2010).

\section{Material and methods}

The nomenclature and metrics used here follow López Martínez \& Thaler (1975) and Angelone \& Sesé (2009). All drawings and measurements were made using a binocular microscope with a camera lucida and ocular micrometer. For consistency, only adult specimens (recognized by their prismatic tooth shape) were used. Abbreviations used in the text and tables are as follows: $\mathrm{Ht}$ - holotype, $\mathrm{L}$ - length, Lt - lectotype, Ltrig - trigonid length, $\mathrm{N}$ - number 
of specimens, OR - observed range, Plt - paralectotype, $\mathrm{W}$ - width, Wtl - third lobe width of $\mathrm{m} 2$, Wtal - talonid width, Wtrig - trigonid width, $\mathrm{X}$ - mean. Capital and lower-case letters, $\mathrm{P} / \mathrm{p}$ (premolar) and $\mathrm{M} / \mathrm{m}$ (molar), refer to upper and lower cheek-teeth, respectively. The material of Prolagus from Gundersheim localities is housed in the $\mathrm{SMF}$, from Raciszyn 1 in the ZPAL. The geographical distance between the two localities is about $750 \mathrm{~km}$.

Comparisons were made with continental European species dating to MN 13-17 and including $P$. savagei Berzi, 1970; P. depereti López Martínez in López Martínez \& Thaler, 1975; P. ibericus López Martínez in López Martínez \& Thaler, 1975; P. michauxi López Martínez in López Martínez \& Thaler, 1975; P. sorbinii Masini, 1989; P. caucasicus Averianov \& Tesakov, 1998; P. italicus Angelone, 2008. All nomenclatural acts presented here conform to the mandatory provisions of the International Code of Zoological Nomenclature (ICZN 1999).

Institutional abbreviations. - SMF - Senckenberg Museum, Frankfurt am Main, Germany; ZPAL - Institute of Paleobiology, Polish Academy of Sciences, Warszawa, Poland.

\section{Results}

\section{Type material of Prolagus bilobus Table 1, Figure 1A, C-F}

Name-bearing type. - The nominal taxon was established by Heller (1936) based on the material from Gundersheim (see below). The name-bearing type is indicated in his original description as: “...several upper teeth, a fragment of right mandible with $\mathrm{m} 1-\mathrm{m} 2$ and one isolated, unfortunately damaged, right p4" [translated from German] (Heller 1936, p. 139). Heller did not designate the holotype (contra Fostowicz-Frelik 2010, p. 610). All the original material of Prolagus published by Heller (1936) is deposited in the $\mathrm{SMF}$, including original labels contained in boxes with the specimens. It is worth to remark, though, that there are inaccuracies in tooth position assignments of the type series in Heller (1936); the material consists of a partly broken left p3 (cut in the bottom part; Heller 1936, fig. 3), a right fragment of mandible with $\mathrm{p} 4-\mathrm{m} 2$, and three fragments of lower molariform teeth, i.e., right talonid of $\mathrm{p} 4$, right talonid of $\mathrm{p} 4$ or $\mathrm{m} 1$ and right trigonid of $\mathrm{p} 4$ or $\mathrm{m} 1$.

The first valid designation of a lectotype (see Articles 74.3 and 74.5 of ICZN 1999) was done by López Martínez \& Thaler (1975). Following Article 74.4 (ICZN 1999) the figured specimen in Heller (1936, fig. 3), SMF 1996/136, is thus the sole name-bearing type of Prolagus bilobus. The later designation of a lectotype provided by Tesakov \& Averianov (2002) must be regarded as invalid.
Size and morphology. - The lectotype is a prismatic p3 of an adult individual. On the occlusal surface the anterior and lingual parts of the tooth are broken (anteroconid, metaconid and entoconid are lacking). All tooth morphostructures are well observable in its bottom transverse section and do not show any major morphological differences from those in more apical parts of the tooth. The $\mathrm{L} \times \mathrm{W}$ of $\mathrm{p} 3$ measured on the tooth shaft is $2.70 \times 2.55 \mathrm{~mm}$. The triangular anteroconid is large (of similar size as the metaconid), lingually elongated, with very shallow posterior and labial indentations, and its central axis is shifted towards the lingual side of the tooth. The metaconid is smooth, quadrangular, connected with the thick entoconid by a relatively wide metaisthmus. The mesoflexid is bent posteriorly. There is no enamel hiatus on the entoconid. On the lingual side the anteroconid and the entoconid are almost vertically aligned, whereas the metaconid protrudes slightly from this line. The crochet is well developed and bent buccally. The centroflexid enamel border is gently folded, and its lateral lobe is longer than the lingual one. The protoisthmus is long and thin, longer and thinner than the metaisthmus. The protoconid is transversally enlarged in its central part and its connection with the thick and relatively short protoconulid is characterized by a spur.

On the poorly-preserved mandible fragment (paralectotype SMF 1994/895) the posterior mental foramen lies under the $\mathrm{m} 1$ : the anterior mental foramen is not preserved. The height of the mandibular body, measured buccally at the level of $\mathrm{p} 4 / \mathrm{m} 1$, is $10.8 \mathrm{~mm}$. On p4-m2, the trigonids lack enamel hiatus in the anterior part and the talonids bear a well-developed anterior isthmus.

\section{Localities of Gundersheim}

The problem. - Since Heller's publication (1936) of the fauna from the quarries near Gundersheim (District Alzey-Worms, Rheinland-Pfalz, Germany), the exact location, age and name of each locality have been the subject of confusion and discussion. There are three abandoned quarries from which the fossil fauna was collected (Tobien 1980; Fejfar \& Čermák pers. obs., June 2006): Gewerkschaftsbruch (N 49 41'05", E $8^{\circ} 10^{\prime} 53^{\prime \prime}$ ), Rosengartenbruch (N 49 41'02", E $8^{\circ} 10^{\prime} 57^{\prime \prime}$ ) and Kesselsteinbruch

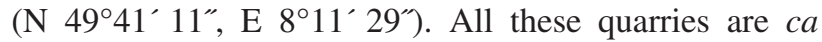
1200-1800 m SW from the midpoint of the Gundersheim village (N 4941'46", E $8^{\circ} 12^{\prime} 09^{\prime \prime}$, the coordinates given by Fostowicz-Frelik (2010, p. 610) for the "type" locality). Most of the fauna from this area was collected by F. Heller and W. Weiler in 1933 (Weiler 1935, Heller 1936) from Rosengartenbruch and Gewerkschaftsbruch. Although F. Heller kept separate the material he collected from different places/fissures of quarries (see Sindowski 1937), he, unfortunately, published all the specimens as one faunal 

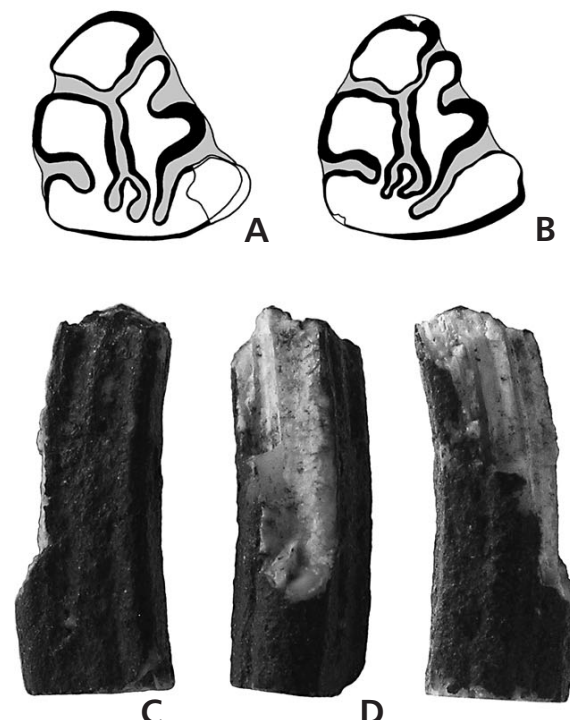

$3 \mathrm{~mm}$
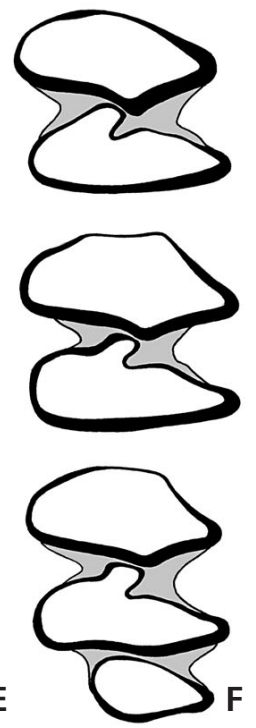

$1 \mathrm{~mm}$
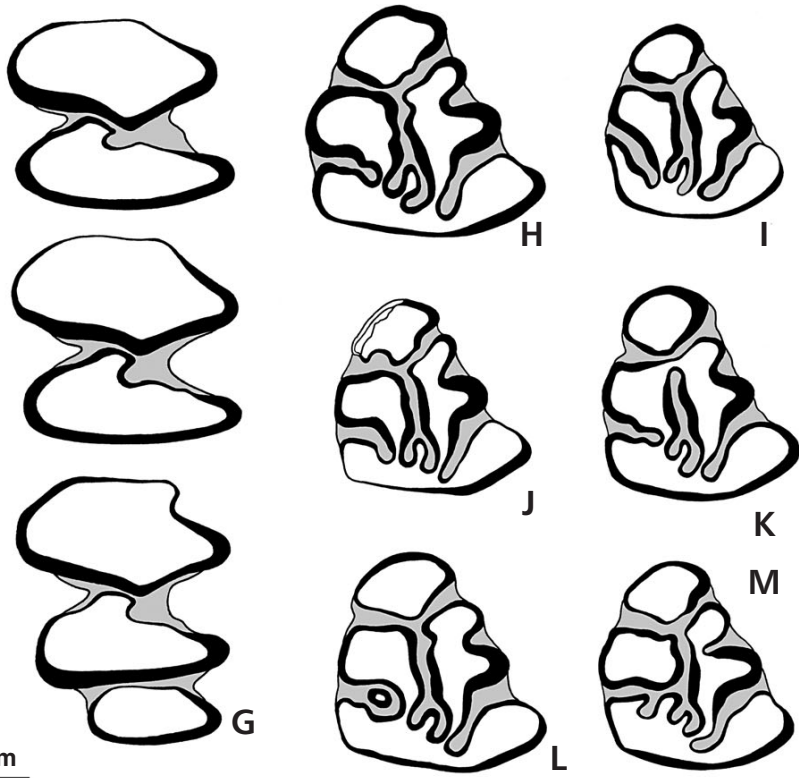

Figure 1. Pliocene Prolagus of central Europe. A A, C-E - lectotype of Prolagus bilobus Heller, 1936, left p3; A - transverse section, C - buccal view, $\mathrm{D}$ - anterior view, E - lingual view. $\bullet \mathrm{B}, \mathrm{G}$ - holotype of $P$. osmolskae Fostowicz-Frelik, 2010; $\mathrm{B}$ - occlusal view of right p3, G - occlusal view of right p4-m2. $\bullet \mathrm{F}$ - paralectotype of $P$. bilobus, occlusal view of right $\mathrm{p} 4-\mathrm{m} 2$. $\bullet \mathrm{H}-\mathrm{M}-\mathrm{p} 3 \mathrm{~s}$ of $P$. bilobus from Gundersheim-Findling, occlusal views (all figured as right specimens; I, J and L are reversed). Scale bars: $3 \mathrm{~mm}$ for photos (grey), $1 \mathrm{~mm}$ for drawings (white).

assemblage with only sporadic notes concerning their original provenance.

Localities and age. - Until the 1960s, all the fauna was generally considered as one faunal complex/assemblage and called simply Gundersheim (e.g., Kretzoi 1956). Later, Kretzoi (1962) divided the rodents from Gundersheim into two faunal units, an older one correlated with the Csarnotanian (sensu Kretzoi 1962; ca MN 15b), and a younger one correlated with the Late Villányian (sensu Kretzoi 1962; ca MN 17). This view was subsequently broadly accepted (see Tobien 1980, for details). Tobien (1980) used numbers to distinguish the different faunal sub-samples of Heller's original collections from Gundersheim. He called the older faunal complex (sensu Kretzoi 1962) as Gundersheim-1 (however this locality was sometimes referred to MN 16a, e.g., in Fejfar \& Heinrich 1981) and the younger one as Gundersheim-2. Tobien (1980) also numbered, parallel to the numbering of the faunas and independently to them, specific karst fissures discovered and studied by him (since the 1950s) in the quarries of Gundersheim. He numbered 22 fissures of which five yielded identifiable faunal remains (fissures Nos. 1, 4, 5, 7 and 11). Among them No. 4 was especially interesting (MN 15b, Fejfar et al. 2006) due to several finds of Trilophomys. Tobien (1980) assumed that the major part of Heller's "Csarnotanian" elements most likely originated from this fissure.

Another Gundersheim fauna was discovered in 1976 and originated from an isolated block of fossiliferous sediment. Fejfar \& Heinrich (1987) called this locality
Gundersheim-Findling. Later, after the arrangement with H. Tobien, Fejfar \& Storch (1990) used the name Gundersheim-4 for this locality. The faunal assemblage from this block was correlated with the Late Ruscinian (MN 15b). The last paper about Gundersheim (Fejfar et al. 2006) described the Ruscinian fauna of fissure No. 4 (sensu Tobien 1980). But, the locality was once again called as Gundersheim-4 (= "Spalte Nr. 4 aus dem Gundersheimer Rosengartenbruch" sensu Dahlmann \& Storch 1996, p. 181, = "undescribed material formerly in the possession of H. Tobien" sensu Fejfar 2001, p. 190). Thus, to avoid a potential misunderstanding, we propose to use the names 'Gundersheim-fissure 4' for the karst fissure No. 4 (sensu Tobien 1980, material described in Fejfar at al. 2006), and 'Gundersheim-Findling' for the isolated block discovered in 1976 (Fejfar \& Storch 1990).

Pliocene Lagomorpha of Gundersheim. - According to Tobien (1974), Heller's original material of P. bilobus comes from the older faunal assemblages, i.e., Gundersheim-1 sensu Tobien (1980). This is strongly supported by other phenotypically comparable finds of Prolagus limited exclusively to the undoubtedly Late Ruscinian (MN 15b) sites Gundersheim-fissure 4 and Gundersheim-Findling. Gundersheim-Findling yielded also the leporid Pliopentalagus dietrichi (Fejfar, 1961), which is typical for MN 15. Moreover, there is no record of Prolagus in the MN 17 of central Europe (Germany, Poland, the Czech Republic, Slovakia, Hungary - except from Kisláng, which is a taphonomic mixture, $c f$. Mayhew 2012); this makes less 
probable that $P$. bilobus comes from the MN 17 locality Gundersheim-2 (sensu Tobien 1980).

\section{Taxonomic validity of Prolagus osmolskae}

The criteria provided by Fostowicz-Frelik (2010) for the discrimination of $P$. osmolskae from $P$. bilobus are (1) the indentation of the posterior margin of $\mathrm{p} 3$ anteroconid (see Diagnosis, p. 609); (2) the size of the p3 of P. osmolskae being much larger than P. bilobus (see Discussion, p. 610). Both remarks are not correct, as we will discuss in the following sections (see also Fig. 1A, B, Table 1).

Size. - The lectotype (p3) of P. bilobus is slightly larger $(\mathrm{L} \times \mathrm{W}=2.70 \times 2.55 \mathrm{~mm})$ than the holotype of $P$. osmolskae $(\mathrm{L} \times \mathrm{W}=2.61 \times 2.42 \mathrm{~mm})$. Fostowicz-Frelik $(2010$, p. 610) underestimated the size of the lectotype of $P$. bilobus $(2.20 \times 2.52 \mathrm{~mm})$ and also stated that " $\ldots$ additional material of $P$. bilobus from the same locality [i.e. Gundersheim-fissure 4] (Fejfar et al. 2006) includes a p3 of definitely smaller size". As shown above, there is no direct evidence that Gundersheim-fissure 4 is the same as the original type locality of $P$. bilobus. At any rate, the size of Prolagus specimens from both Gundersheim localities is very variable. A direct observation of material from Gundersheim-fissure 4 published by Fejfar et al. (2006) proved the presence of very large specimens. For example P3 SMF 2005/3 $(\mathrm{L}=2.31 \mathrm{~mm})$ falls even over the dimensional range ( $\mathrm{L}: \mathrm{OR}=1.94-2.21 \mathrm{~mm}$, $\mathrm{N}=7$ ) of adult P3 specimens from GundersheimFindling. The measurements of $\mathrm{p} 3$ of $P$. osmolskae also fall in the observed range [OR $\mathrm{L} \times \mathrm{W}=(2.28-2.77 \mathrm{~mm})$ $\times(2.11-2.57 \mathrm{~mm}), \mathrm{X}=2.52 \times 2.30 \mathrm{~mm}, \mathrm{~N}=6]$ of comparative adult $\mathrm{p} 3 \mathrm{~s}$ from the equally relevant locality Gundersheim-Findling.

Morphology. - The name-bearing specimens of $P$. bilobus and $P$. osmolskae share on the p3 a: (1) large triangular anteroconid (of similar size as metaconid), which is indented posteriorly and buccally and whose central axis is shifted towards the lingual side of the tooth; (2) enamel folded around the centroflexid; (3) very well-developed and buccally bent crochet; (4) quadrangular metaconid; (5) well-developed protoconid and protoconulid; (6) long and thin protoisthmus; and (7) thick entoconid lacking enamel hiatus. In addition, the specimens from Gundersheim (Fig. 1H-M) show a tendency to plication of the $\mathrm{p} 3$ enamel pattern and to variability in the presence of standard additional lophids or enamel islets (note specimens with closed centroflexid, Fig. 1K; mesoflexid with enamel islet, Fig. 1L; or isolated metaconid, Fig. 1M). Considering the morphology of mandible, apart from the same position of the posterior mental foramen (under the $\mathrm{m} 1$ ), no other observation can be made within the type series.

\section{Conclusions and summary}

The data above establish that $P$. bilobus is not "noticeably smaller" (Fostowicz-Frelik 2010, p. 610) than P. osmolskae. The confusing measurements of the lectotype of P. bilobus in Fostowicz-Frelik (2010), were most likely taken at the broken occlusal part of the tooth ( $\mathrm{Lx} \mathrm{W} \sim 2.20 \times$ 2.50 as measured by SC). This resulted in a misleading taxonomical consideration of the specimen from Raciszyn 1. Thus, considering the size and morphological variability of Prolagus from Gundersheim, the almost identical p3 size and morphology of the lectotype of $P$. bilobus and holotype of $P$. osmolskae, and the age and geographical distance (without any major barrier) of the type localities under study, it is proposed to consider Prolagus osmolskae Fostowicz-Frelik, 2010 as a junior subjective synonym of P. bilobus Heller, 1936. In conclusion, the above can be summarized as shown in the following chapter.

\section{Systematic palaeontology}

Order Lagomorpha Brandt, 1855

Family Prolagidae Gureev, 1960

\section{Genus Prolagus Pomel, 1853}

\section{Prolagus bilobus Heller, 1936}

Table 1, Figure 1

Synonym. - Prolagus osmolskae Fostowicz-Frelik, 2010, p. 609 , fig. 1 (original description).

Lectotype. - SMF 1996/136, left p3, illustrated in Heller (1936, fig. 3).

Paralectotypes. - SMF 1994/895, right mandible fragment with p4-m2; SMF 1994/896, right talonid of p4; SMF 1994/897, right talonid of p4 or m1; SMF 1996/137, right trigonid of $\mathrm{p} 4$ or $\mathrm{m} 1$.

Type locality and age. - Gundersheim (probably Gundersheim-1 sensu Tobien 1980; MN 15b-16a), Rheinland-Pfalz, Germany; the exact age uncertain (within the possible age range, taking into account phenotypically comparable finds of Prolagus from other localities of Gundersheim, a referral to MN $15 \mathrm{~b}$ seems to be most likely).

Referred material. - ZPAL M.10, right mandible body with complete dentition (Raciszyn 1, MN 15b); SMF 
Stanislav Čermák \& Chiara Angelone • Revision of the Pliocene species Prolagus bilobus

Table 1. Tooth measurements of type material of Pliocene Prolagus of central Europe $(*=$ tooth fragment of uncertain determination, $\mathrm{p} 4$ or $\mathrm{m} 1)$.

\begin{tabular}{|c|c|c|c|c|c|c|c|c|c|c|c|c|c|c|c|}
\hline \multirow{2}{*}{$\begin{array}{l}\text { Species } \\
\text { Specimen No. }\end{array}$} & \multirow[b]{2}{*}{ Type } & \multicolumn{2}{|c|}{ p3 } & \multicolumn{4}{|c|}{$\mathrm{p} 4$} & \multicolumn{4}{|c|}{ m1 } & \multicolumn{4}{|c|}{$\mathrm{m} 2$} \\
\hline & & $\mathrm{L}$ & W & $\mathrm{L}$ & Ltrig & Wtrig & Wtal & $\mathrm{L}$ & Ltrig & Wtrig & Wtal & $\mathrm{L}$ & Wtrig & Wtal & Wtl \\
\hline \multicolumn{16}{|l|}{ Prolagus bilobus } \\
\hline SMF 1996/136 & $\mathrm{Lt}$ & 2.70 & 2.55 & & & & & & & & & & & & \\
\hline SMF 1994/895 & Plt & & & 2.20 & 1.27 & 2.40 & 2.36 & 2.32 & 1.27 & 2.50 & 2.44 & 2.93 & 2.28 & 2.24 & 1.43 \\
\hline SMF 1994/896 & Plt & & & & & & 2.31 & & & & & & & & \\
\hline SMF 1994/897 & Plt & & & & & & $1.76 *$ & & & & & & & & \\
\hline SMF 1996/137 & Plt & & & & $1.12 *$ & $2.25^{*}$ & & & & & & & & & \\
\hline \multicolumn{16}{|l|}{ Prolagus osmolskae } \\
\hline ZPAL M.10 & $\mathrm{Ht}$ & 2.61 & 2.42 & 2.25 & 1.36 & 2.36 & 2.40 & 2.48 & 1.42 & 2.59 & 2.47 & 3.10 & 2.41 & 2.11 & 1.45 \\
\hline
\end{tabular}

2005/3, left P3 (Gundersheim-fissure 4, MN 15b); SMF 1985/77-83, 3 left and 4 right P3s; SMF 1985/159-164, 3 left and 3 right p3s (Gundersheim-Findling, MN 15b).

Emended diagnosis. - Very large p3 (largest one among the continental European MN 13-17 species) with lingually shifted, large, triangular, posteriorly and buccally indented anteroconid; crenulated centroflexid, long and buccally bent crochet; metaconid of similar size as anteroconid; thick entoconid lacking enamel hiatus. Lower third premolar differs from that in: (1) P. depereti, $P$. ibericus, $P$. italicus, $P$. savagei in having a larger crochet; (2) $P$. caucasicus in having a quadrangular metaconid; and (3) $P$. michauxi, $P$. sorbinii in having a triangular indented anteroconid, which is vertically aligned with the entoconid.

Stratigraphic and geographic distribution. - Early/?Late Pliocene (MN 15b/?16a); localities Gundersheim-1, Gundersheim-fissure 4, Gundersheim-Findling, possibly Wölfersheim (all in Germany) and Raciszyn 1 (Poland); central Europe.

\section{Acknowledgments}

We wish to convey our sincere thanks to O. Fejfar (Charles University, Prague) for valuable information on the material and localities of Gundersheim, J. Wagner (Academy of Sciences of the Czech Republic, Prague) for providing bibliographic data on Gundersheim and for inspiring discussion. We are very indebted to A. Winkler (Southern Methodist University, Texas) for corrections of English and for constructive remarks. We are also grateful to K. Krohmann (SMF), A.T. Halamski (ZPAL) and M. Borsuk-Białynicka (ZPAL) for providing us the fossil material in their care. Last but not least, we express our sincere thanks to S. Sen (Muséum national d'Histoire naturelle, Paris) and an anonymous reviewer for their critical reading and helpful comments on the manuscript. This study was supported by grant No. GA205/09/0184 from the Grant Agency of the Czech Republic and partly by the Academic Project of the Institute of Geology in Prague No. AV0Z30130516.

\section{References}

Angelone, C. 2008. Prolagus italicus n. sp. (Ochotonidae, Lagomorpha, Mammalia) a new Pliocene species of peninsular Italy. Geobios 41, 445-453.

DOI 10.1016/j.geobios.2007.12.001

Angelone, C. \& SeSÉ, C. 2009. New characters for species determination within the genus Prolagus (Ochotonidae, Lagomorpha, Mammalia). Journal of Paleontology 83(1), 80-88. DOI 10.1666/07-067R2.1

Averianov, A.O. \& Tesakov, A.C. 1998. The Lagomorpha (Mammalia) from the early Pliocene Kosyakino locality of the northern Caucasus. Paleontological Journal 32, 91-96. [in Russian]

BERZI, A. 1970. Lagomorphs from the type Villafranchian of Villafranca d'Asti (Italy). Preliminary note. Giornale di Geologia 35, 137-150.

BRANDT, J.F. 1855. Beiträge zur näheren Kenntniss der Säugethiere Russlands. Mémoire de l'Académie impériale des Sciences, St. Petersburg, Physique, Mathématique, et Naturalistique, Séries 6(9), 1-365.

Dahlmann, T. \& Storch, G. 1996. Eine pliozäne (oberruscinische) Kleinsäugerfauna aus Gundersheim, Rheinhessen. 2. Insektenfresser: Mammalia, Lipotyphla. Senckenbergiana lethaea 76, 181-191.

FeJFAR, O. 1961. Die plio-pleistozänen Wirbeltierfaunen von Hajnáčka und Ivanovce (Slowakei), ČSSR. III. Lagomorpha. Neues Jahrbuch für Geologie und Paläontologie, Monatshefte $5,267-282$.

FeJfar, O. 2001. The Arvicolids from Arondelli-Triversa: a new look. Bollettino della Società Paleontologica Italiana 40(2), 185-193.

FeJfar, O. \& HeINRICH, W.-D. 1981. Zur biostratigraphischen Untergliederung des kontinentalen Quartärs in Europa anhand von Arvicoliden (Rodentia, Mammalia). Eclogae geologicae Helvetiae 74(3), 997-1006.

FeJfar, O. \& HeInRICH, W.-D. 1987. Zur biostratigraphischen Gliederung des jüngeren Känozoikums in Europe an Hand von Muriden und Cricetiden (Rodentia, Mammalia). Časopis pro mineralogii a geologii 32(1), 1-16.

FeJfAR, O. \& Storch, G. 1990. Eine pliozäne (ober-ruscinische) Kleinsäugerfauna aus Gundersheim, Rheinhessen: 1. Nagetiere: Mammalia, Rodentia. Senckenbergiana lethaea 71(1/2), 139-184. 
Fejfar, O., Storch, G. \& Tobien, H. 2006. Gundersheim 4, a third Ruscinian micromammalian assemblage from Germany. Palaeontographica A 278, 97-111.

Fostowicz-Frelik, Ł. 2010. A new species of Pliocene Prolagus (Lagomorpha, Ochotonidae) from Poland is the northernmost record of the genus. Journal of Vertebrate Paleontology 30(2), 609-612. DOI 10.1080/02724631003621789

GuREev, A.A. 1960. Lagomorphs (Lagomorpha) from the Oligocene of Mongolia and Kazakhstan. Trudy Paleontologicheskogo Instituta AN SSSR 77, 5-34. [in Russian]

HelleR, F. 1936. Eine oberpliozäne Wirbeltierfauna aus Rheinhessen. Neues Jahrbuch für Mineralogie, Geologie und Paläontologie, Abteilung B 76, 99-160.

ICZN [InTERnATIONAL COMmission on Zoological NomenclaTURE] 1999. International Code of Zoological Nomenclature, $4^{\text {th }}$ edition. XXIX + $306 \mathrm{pp}$. International Trust for Zoological Nomenclature, London.

KretzoI, M. 1956. Die altpleistozänen Wirbeltierfaunen des Villányer Gebirges. Geologica hungarica, Series palaeontologica 27, 1-264.

KretzoI, M. 1962. Fauna und Faunenhorizont von Csarnóta. Jahresbericht der Ungarischen geologischen Anstalt 1959, 297-395.

López Martínez, N. \& Thaler, L. 1975. Biogéographie, évolution et complements à la systématique du groupe d'Ochotonides Piezodus-Prolagus (Mammalia, Lagomorpha). Bulletin de la Société géologique de France 17(5), 850-866.

Masini, F. 1989. Prolagus sorbinii n. sp., a new ochotonid (Mammalia, Lagomorpha) from the Messinian of Italy. Bolletino della Società Paleontologica Italiana 28, 295-306.

MAYHEw, D.F. 2012. Revision of the fossil vole assemblage
(Mammalia, Rodentia, Arvicolidae) from Pleistocene deposits at Kisláng, Hungary. Palaeontology 55, 11-29. DOI 10.1111/j.1475-4983.2011.01115.x

Pomel, A. 1853. Catalogue méthodique et descriptif des vertébrés fossiles découverts dans le bassin hydrographique supérieur de la Loire, et surtout dans la vallée de son affluent principal, l'Allier. 193 pp. J.-B. Baillière, Paris, Londres, New York, Madrid.

Sindowski, K.-H. 1937. Zur Sedimentpetrographie des Oberpliozäns und Altdiluviums der mittleren Oberrheinebene. Zeitschrift der Deutschen Geologischen Gesellschaft 89(10), 409-418.

Tesakov, A.C. \& Averianov, A.O. 2002. Prolagus (Lagomorpha, Prolagidae) from the Pliocene of Moldova and Ukraine. Paleontological Journal 36, 85-91. [in Russian]

ToBIEN, H. 1974. Villafranchian Mammals in Western Germany. Mémoires du Bureau de recherches géologiques et minères 78(1), 259-265.

Tobien, H. 1977. 7. Fauna, 65-68. In Boenigk, W., Brelie, G., Brunnacker, K., Kempf, E.K., Kočí, A., Schirmer, W., Stadler, G., Streit, R. \& Tobien, H. (eds) Jungtertiär und Quartär im Horloff-Graben/Vogelsberg, Geologische Abhandlungen Hessen 75.

Tobien, H. 1980. Säugerfaunen von der Grenze Pliozän/Pleistozän in Rheinhessen. 1. Die Spaltfüllungen von Gundersheim bei Worms. Mainzer geowissenschaftliche Mitteilungen 8, 209-218.

WEILER, W. 1935. Neue geologische und paläontologische Untersuchungen im südlichen Rheinhessen. Notizblatt des Vereins für Erdkunde und der Hessischen geologischen Landesanstalt zu Darmstadt für das Jahr 1934, V. Folge 16, 56-81. 